DE

M E D I C I N A

T R O P I C A L

$\mathrm{DE}$

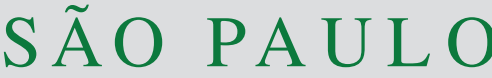

JOURNAL OF THE SÃO PAULO INSTITUTE OF TROPICAL MEDICINE

${ }^{1}$ Universidade do Sul de Santa Catarina, Programa de Pós-Graduação em Ciências da Saúde, Tubarão, Santa Catarina, Brazil

${ }^{2}$ Secretaria de Estado da Saúde de São Paulo, Coordenadoria de Controle de Doença, Instituto Adolfo Lutz, Centro de Imunologia, São Paulo, São Paulo, Brazil

Correspondence to: Adele Caterino-deAraujo

Secretaria de Estado da Saúde de São Paulo, Coordenadoria de Controle de Doença, Instituto Adolfo Lutz, Centro de Imunologia, Av. Dr. Arnaldo, 351, $11^{\circ}$ andar, CEP 01246-000, Pacaembu, São Paulo, SP, Brazil

Tel: $+55113068-2898$

E-mail: adele.caterino@ial.sp.gov.br, caterino@alumni.usp.br

Received: 24 June 2019

Accepted: 9 September 2019

\section{The first survey of human T-cell lymphotropic viruses (HTLV) in HIVIAIDS patients in Santa Catarina State, Brazil}

Chaiana Esmeraldino Mendes Marcon', Karoline Rodrigues Campos², Gabriela Bassi da Silva², Fabiana Schuelter-Trevisol' ${ }^{1}$, Aline Daiane Schlindwein' ${ }^{1}$, Daisson José Trevisol ${ }^{1}$, Adele Caterino-de-Araujo ${ }^{\circledR 2}$

\section{ABSTRACT}

Santa Catarina is a Brazilian State that has reported the lowest prevalence of human T-cell lymphotropic viruses (HTLV-1/2) in blood donors (0.04\%). Although it presents ports, airports and roads that facilitate the entrance and dissemination of new infectious agents, no information exists concerning the HTLV-1/2 infections in HIV/AIDS patients. This study searched for HTLV-1/2 antibodies in plasma samples of 625 HIV/AIDS patients from the municipality of Tubarao (Southern Santa Catarina), and disclosed $1.1 \%$ of positivity $(0.48 \%$ HTLV-1, $0.48 \%$ HTLV-2 and $0.16 \%$ untypeable HTLV), and a positive correlation with the male sex (OR 4.16) and intravenous drug use (OR 35.18). Although the percentage of $1.1 \%$ appears to be low, it is 27.5 times higher than the percentage detected in blood donors. Since HTLV-1 and HTLV-2 are circulating in HIV-infected individuals in Southern Santa Catarina, and these retroviruses could cause a differently impact on the HIV/AIDS outcomes, the surveillance of HTLV-1/2 is necessary, and it could support public health policies in preventing the transmission and dissemination of these viruses in this State.

KEYWORDS: HTLV-1. HTLV-2. HIV. Santa Catarina State. Brazil.

\section{INTRODUCTION}

The first retrovirus identified in human beings, named human T-cell lymphotropic virus type 1 (HTLV-1), has been the etiological agent of at least two important diseases of high lethality and morbidity: the adult T-cell leukemia/lymphoma (ATLL) and the HTLV-1-associated myelopathy/tropical spastic paraparesis (HAM/TSP) ${ }^{1,2}$. The second human retrovirus, named HTLV-2, although originally isolated from a patient with hairy T-cell leukemia, was later not confirmed to be associated with the specific disease, making its pathogenicity questionable ${ }^{1}$. Nonetheless, when these human retroviruses are associated with HIV, they are claimed to affect the HIV patient's progression towards AIDS. HTLV-1 has been associated with the rapid progression and death due to $\mathrm{AIDS}^{3,4}$, whereas the HTLV-2 has been associated with slow progression towards AIDS ${ }^{5}$. Thus, the search for HTLV-1/2 in HIV-infected individuals has a prognostic value.

Brazil, a country of more than 200 million inhabitants, is an important endemic area for HTLV-1 infection and associated diseases in the world, estimated to 800,000 HTLV-1-infected people ${ }^{2}$. HTLV-2 is endemic among the indigenous populations of the Brazilian Amazon region and among intravenous drug users (IDU) in urban areas, co-infected or not with HIV ${ }^{6}$. The Brazilian Ministry of Health recommends HTLV-1/2 serological testing at the beginning 
of HIV-1-infected patients' follow-up, mostly in regions where the HTLV-1 is endemic ${ }^{7}$.

Despite having a heterogeneous geographic distribution in Brazil, HTLV-1/2 discloses the lowest prevalence rate in blood donors $(0.4 / 1.000$ blood donors or $0.04 \%)$ in the Santa Catarina State 8,9 , which has 47,461 cases of AIDS. The data collected during the period from 2000 to 2017 showed an AIDS notification rate of 26.8 cases per 100,000 inhabitants, which is higher than the national rate (18.3 per 100,000 inhabitants), described during this period ${ }^{10,11}$.

There are no data available regarding HTLV-1 and HTLV-2 in HIV-1-infected individuals from Santa Catarina State. Considering that the airports, ports and roads of this State facilitate the entrance and dissemination of new infectious agents, as occurred with the HIV-1 subtype C in Brazil ${ }^{12}$, a survey on HTLV-1/2 infection is necessary and relevant.

\section{MATERIALS AND METHODS}

A cross-sectional study on HTLV-1/2 serology was conducted by analyzing plasma samples from 625 HIV/AIDS patients with a mean age of 43 years (range 18-84 years, $59.4 \%$ men) attending a specialized HIV/AIDS diagnosis and treatment center in the municipality of Tubarao (Centro de Atendimento Especializado em Saude - CAES). The CAES has registered 1,417 patients, including those with tuberculosis and hanseniasis, encompassing 18 municipalities of Southern Santa Catarina: Armazem, Braco do Norte, Capivari de Baixo, Grao Para, Gravatal, Imarui, Imbituba, Jaguaruna, Laguna, Pedras Grandes, Pescaria Brava, Rio Fortuna, Sangao, Santa Rosa de Lima, Sao Ludgero, Sao Martinho, Treze de Maio and Tubarao.

Blood samples were collected from the patients from October 2016 to July 2017 to determine CD4 and CD8 cell counts and HIV viral load quantification, and only plasma samples were stored in a repository for further analysis. The socio-demographic data and the potential risk factors for HIV infection were obtained from a standardized individual questionnaire, which was applied by a trained interviewer. Data concerning the number of CD4 cell counts, HIV viral load quantification, highly active antiretroviral therapy (HAART) usage, and clinical manifestations were obtained from medical records. The stored plasma samples were sent to the Instituto Adolfo Lutz (IAL), a Public Health Laboratory in Sao Paulo, for the detection of HTLV-1/2 antibodies. These samples were analyzed after obtaining the informed consent from patients, and the protocol approval from the Ethic Committees of both institutions [IAL, CAAE N ${ }^{\circ}$ 96885118.6.3001.0059, and Universidade do Sul de Santa Catarina (UNISUL) and CAES, CAAE
$\left.\mathrm{N}^{\circ} 96885118.6 .0000 .5369\right]$. All procedures were performed in accordance with the Resolution 466/2012 of the Brazilian National Health Council (CNS) on Ethics in Research with Human Beings.

The plasma samples were screened for HTLV-1/2 antibodies at the HTLV Research Laboratory of the Immunology Department of IAL by using an enzyme linked-immunosorbent assay Gold ELISA HTLV-1/2 (REM Industria e Comercio LTDA, Sao Paulo, Brazil), and confirmed by Western Blot (WB) (HTLV BLOT 2.4, MP Biomedicals, Asia Pacific Pte Ltd, Singapore) and line Immunoassay (INNO-LIA HTLV I/II, Fujirebio, Europe N.V, Belgium). Reactions were performed and interpreted according to the manufacturer's instructions. Noteworthy, HTLV-1/2 molecular confirmatory assay was not performed because of the lack of cells for analysis.

\section{RESULTS}

The screening assay detected eight reactive samples. HTLV-1/2 infection was confirmed in seven samples (1.1\%): HTLV-1 (0.48\%), HTLV-2 (0.48\%), and HTLV positive but untypeable $(0.16 \%)$. An association between male individuals and IDUs was observed (Table 1). In relation to the age, although the coinfected patients had a mean age of 49.7 years old, their HIV-mono-infected counterparts had a mean age of 42.9, but no statistic difference was observed. However, six out of seven HIV/HTLV-coinfected patients were aged 48 to 60 years old; and only one was 29 years old. The distribution of patients according to the age group is in Figure 1, emphasizing that the majority of HIV/HTLVcoinfected patients were aged 51 to 60 years old.

Of note, among HIV/AIDS patients $88.1 \%$ were on HAART and $74.1 \%$ had undetectable HIV viral load. Among HIV/HTLV-coinfected patients, all except one were on HAART and had undetectable HIV viral load. The naïve patient was a man of 52 years old, IDU, HIV/ HCV/HTLV-1-coinfected, with a CD4 count of 273 cells/ $\mathrm{mm}^{3}$ and HIV viral load of 77,491 copies/mL, and he died of pneumonia. Another coinfected patient who died during follow-up was the 29 years old man. Curiously he was HIV/ HTLV-2-coinfected, denied IDU, had a CD4 count of 635 cells $/ \mathrm{mm}^{3}$ and undetectable HIV viral load; had a history of syphilis, tuberculosis and pneumocystosis, and died after a non characterized heart attack. The other coinfected patients remain alive, on HAART, and with HIV undetectable viral load. None HIV/HTLV-coinfected patient presented any HTLV-associated neurological diseases.

Comparative analysis of CD4 cell counts among HIV/ AIDS mono-infected patients (mean of $507.5 \mathrm{cells} / \mathrm{mm}^{3}$ ) and coinfected patients (mean of 403.0 cells $/ \mathrm{mm}^{3}$ in HIV/ 
Table 1 - Demographic characteristics (number, age, sex and risk factors) of overall HIV-infected and HIV/HTLV-1/2-coinfected patients from Tubarao, Santa Catarina State, Brazil.

\begin{tabular}{|c|c|c|c|c|c|}
\hline \multirow{2}{*}{$\begin{array}{l}\text { Demographic } \\
\text { characteristics of } \\
\text { patients }\end{array}$} & \multirow{2}{*}{ HIV (n=618) } & \multicolumn{3}{|c|}{ HTLV } & \multirow{2}{*}{ OR (Cl 95\%) } \\
\hline & & HTLV-1 (n=3) & HTLV-2 (n=3) & $\operatorname{HTLV}(n=1)$ & \\
\hline \multicolumn{6}{|l|}{ Age in years ${ }^{1}$} \\
\hline Female & 42.7 & 60.0 & - & - & \\
\hline Male & 43.0 & 50.0 & 43.0 & 59.0 & \\
\hline \multicolumn{6}{|l|}{$\operatorname{Sex}^{2}$} \\
\hline Female & $253(40.9)$ & $1(14.3)$ & - & - & \\
\hline Male & $365(59.1)$ & $2(28.6)$ & $3(42.8)$ & $1(14.3)$ & $4.16(0.50-92.22)$ \\
\hline \multicolumn{6}{|l|}{ Exposure to HIV² } \\
\hline Sexual & $433(70.0)$ & $1(14.3)$ & $1(14.3)$ & - & \\
\hline IDU & $41(6.6)$ & $2(28.6)$ & $2(28.6)$ & $1(14.3)$ & $35.18(5.80-271.11)$ \\
\hline Mother-to-child & $11(1.8)$ & - & - & - & \\
\hline Blood transfusion & $5(0.8)$ & - & - & - & \\
\hline Accident with blood & $15(2.4)$ & - & - & - & \\
\hline Unknown & $113(18.3)$ & - & - & - & \\
\hline
\end{tabular}

${ }^{1}$ Median; ${ }^{2}$ Number (\%); n: number of individuals; IDU: intravenous drug user; OR: odds ratio; CI: confidence interval of $95 \%$.

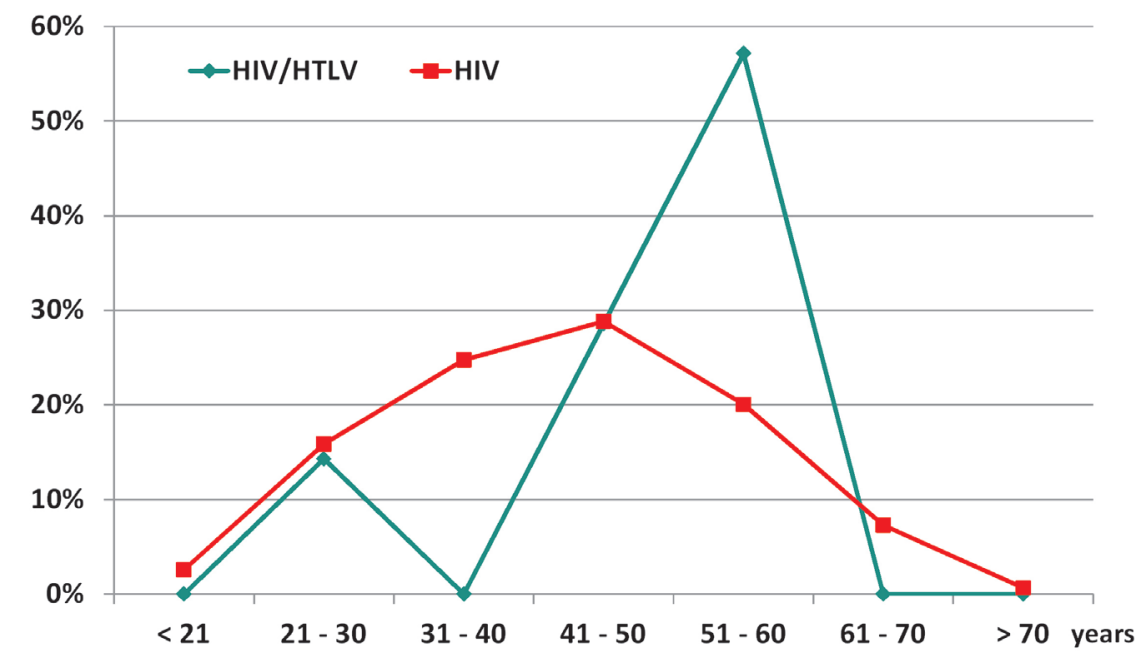

Figure 1 - Percentages of overall HIV-infected and HIV/HTLV-1/2-coinfected patients from Southern Santa Catarina, Brazil, according to the age group.

HTLV-1, 475.0 cells $/ \mathrm{mm}^{3}$ in HIV/HTLV-2, and 145.0 cells/ $\mathrm{mm}^{3}$ in HIV/HTLV co-infected patient) were not feasible because of the low number of HIV/HTLV-1/-2-coinfected individuals. Thus, neither clinical nor statistical correlations were performed.

\section{DISCUSSION}

Although the percentage of $1.1 \%$ of HTLV-1/2 seropositivity appears to be low, it is 27.5 times higher than the positivity detected in blood donors in Santa Catarina State $^{8,9}$, and this is of concern. In addition, both HTLV-1 and
HTLV-2 circulate in this region, and this is somewhat similar to that observed in Sao Paulo State where both, HTLV-1 and HTLV-2 were detected in HIV/AIDS patients ${ }^{13-15}$. In fact, this could be due in part to the mixed population living in Sao Paulo, which is composed of immigrants and migrants from elsewhere in the country and in the same way, this is the same situation found in Southern Santa Catarina. This region has an airport, two ports (Imbituba and Laguna), and the federal freeway BR101 beside others, allowing the contact with foreign people within Brazil, coming from Latin American countries and abroad (Figure 2). In addition, the transmission route and the age of HIV/HTLV-coinfected patients from 


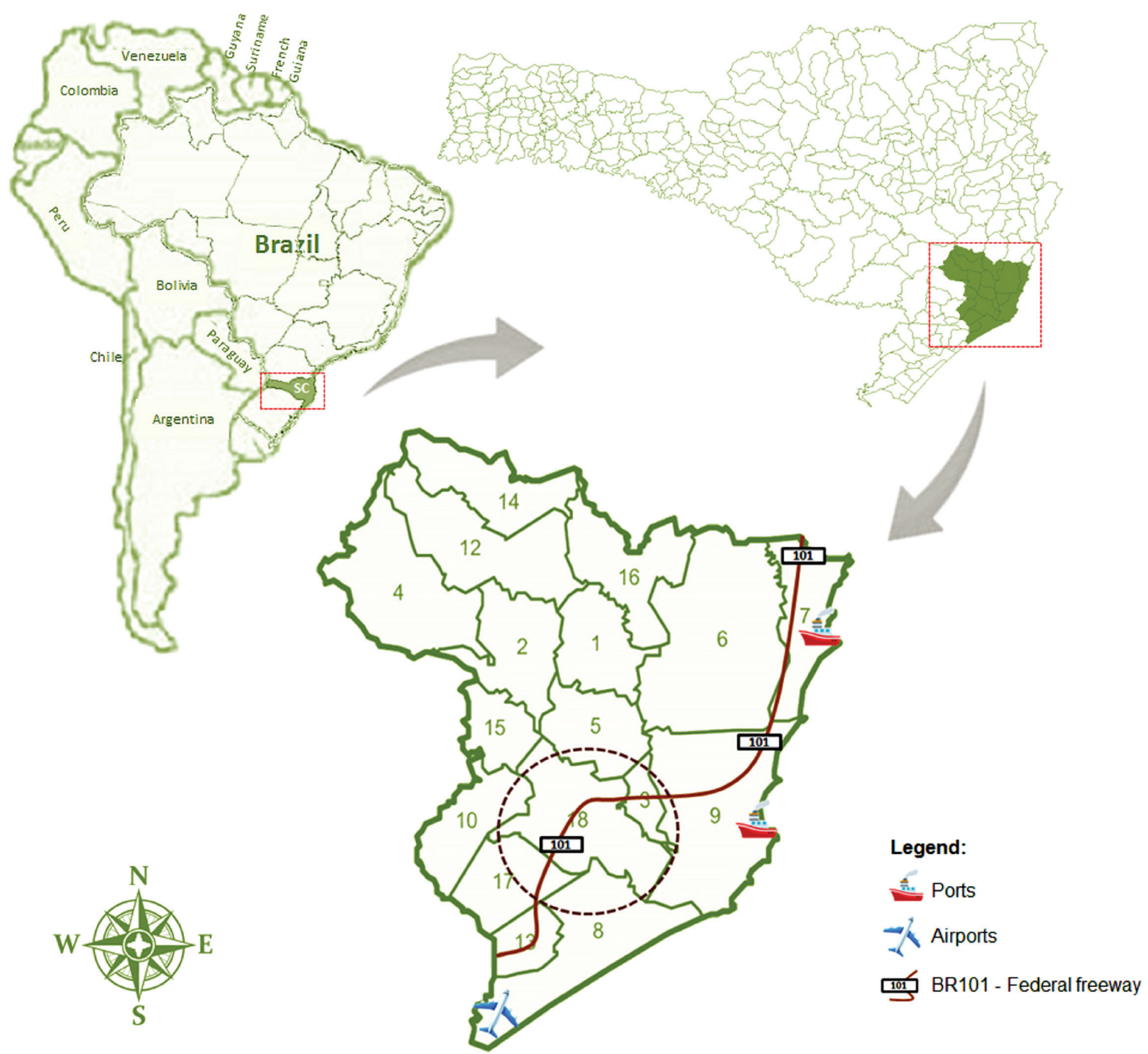

Figure 2 - Maps of the Latin America, Brazil, and Santa Catarina State, with emphasis on the Laguna region, and the 18 municipalities from where blood samples were collected. Location of the airport, the ports [Imbituba (North) and Laguna (South)], the freeway BR101 and the municipality of Tubarao are depicted.

Sao Paulo and Southern Santa Catarina are quite similar. In both States, there was a strong association with IDU (OR 30.01 and OR 35.18, respectively), and the mean age of 50 years old was observed ${ }^{13}$. Interestingly, the only patient of 29 years old acquired HIV and probably HTLV-2 by sexual route, and although on HAART, presenting undetectable viral load and a good CD4 cells count, he died as a consequence of a fulminant heart attack, probably due to lipodystrophy.

Worthy of note, only one study concerning HTLV-1/2 in at-risk individuals from Santa Catarina is available. It was conducted by our group, analyzing 90 female sex workers from the same geographical region of this study. One HTLV-1-positive pregnant woman was detected, and she was advised not to breastfeed her offspring ${ }^{16}$.
Other studies from Southern Brazil were carried out in the municipality of Londrina, Parana State, Brazil. High percentages of HIV/HTLV-coinfections in $758 \mathrm{HIV/}$ AIDS patients $(5.7 \%)$ were found, and there was also association with IDU (OR 10.72) and HCV (OR 30.36). A high prevalence of HTLV-2 as compared to HTLV-1 (4.9\% versus $0.8 \%$, respectively) was detected ${ }^{17,18}$.

One study conducted in Porto Alegre, Rio Grande do Sul State, Brazil showed the occurrence of $2.4 \%$ of HIV/ HTLV coinfection (1.4\% HTLV-1, 0.5\% HTLV-2, and $0.5 \%$ untypeable HTLV) in 2,985 patients, seen at three HIV counseling centers in Porto Alegre, associated with intravenous cocaine use $(p<0.001)$ and HIV positivity $(p<0.001)^{19}$. 
More recently, another study employing molecular assays for confirming HTLV-1/2 infections, conducted on 580 HIV-infected individuals from the metropolitan area of Porto Alegre, showed $2.9 \%$ of HIV/HTLV- $1 / 2$ coinfection $(1.9 \% \text { HTLV-1 and } 1.0 \% \text { HTLV-2 })^{20}$. All of these studies confirm the occurrence of HTLV-1 and HTLV-2 in Southern Brazil.

Noteworthy, at present the major routes of HTLV transmission in Brazil are the sexual and the vertical ${ }^{21}$, but from 1980 to 2000, the parenteral route predominated, mostly among IDU who became infected with HTLV-2 in the South and Southeast regions in Brazil, as previously described $^{13,15,18,22,23}$. On the other hand, in the Northeast Brazil, HTLV-1 predominated among IDU ${ }^{24}$, and these findings could be related to the differences in HTLV-1 and HTLV-2 endemic areas, as well to the different patterns of drug usage. In fact, studies from 2000, described the Brazilian Harm Reduction Programs that provided sterile syringes and needles to IDU, and the change in drug use from intravenous cocaine to crack cocaine. They emphasize the drastic reduction in the number of HIV, and probably HTLV infected individuals in Brazil ${ }^{13,25,26}$. Herein, the older age of HIV/HTLV-coinfected patients, and the strong association with the male sex and IDU corroborate these data.

Taken together, the results detected in this first survey on HTLV-1/2 in HIV/AIDS patients from Southern Santa Catarina revealed the occurrence of HTLV-1 and HTLV-2 circulating among HIV-infected individuals. Given that these retroviruses could cause different impacts on HIV/ AIDS outcomes, the surveillance of HTLV-1/2 is necessary, and it could support public health policies in preventing the transmission of these retroviruses. The authors of the present study are currently interested in expanding these data, searching for sexually transmitted diseases, including HTLV-1/2 in other at-risk populations, such as sex workers, lesbians, gays, bisexual men, and transgender individuals from this geographical area.

\section{ACKNOWLEDGMENTS}

The authors are indebted to Rafael Xavier da Silva for his technical assistance, to Mirthes Ueda for helpful comments, and to Wilson Schuelter (Wicfast) for providing English language revision. This study was supported by CAPES code 001 (scholarship to KRC), CNPq (scholarship to GBS), FAPESP (grant No 2016/03654-0), CCD-SES/SP, IAL, and Fundacao UNISUL.

\section{AUTHORS' CONTRIBUTIONS}

ACA, CEMM and FST contributed to the study conception and design; CEMM, FST, ADS, DJT attended patients, applied the questionnaire and obtained the data and the informed consent from patients; GBS and KRC performed the lab experiments; ACA and KRC analyzed the data and wrote the manuscript. All authors have read the paper and approved the final version.

\section{CONFLICT OF INTERESTS}

The authors declare that they have no conflict of interests.

\section{REFERENCES}

1. Gallo RC. History of the discoveries of the first human retroviruses: HTLV-1 and HTLV-2. Oncogene. 2005;24:592630.

2. Gessain A, Cassar O. Epidemiological aspects and world distribution of HTLV-1 infection. Front Microbiol. 2012;3:388.

3. Brites C, Alencar R, Gusmão R, Pedroso C, Netto EM, PedralSampaio D, et al. Co-infection with HTLV-1 is associated with a shorter survival time for HIV-1-infected patients in Bahia, Brazil. AIDS. 2001;15:2053-5.

4. Brites C, Sampaio J, Oliveira A. HIV/human T-cell lymphotropic virus coinfection revisited: impact on AIDS progression. AIDS Rev. 2009;11:8-16.

5. Beilke MA. Retroviral coinfections: HIV and HTLV: taking stock of more than a quarter century of research. AIDS Res Hum Retroviruses. 2012;28:139-47.

6. Paiva A, Casseb J. Origin and prevalence of human T-lymphotropic virus type 1 (HTLV-1) and type 2 (HTLV-2) among indigenous populations in the Americas. Rev Inst Med Trop Sao Paulo. 2015;57:1-13.

7. Brasil. Ministério da Saúde. Secretaria de Vigilância em Saúde. Departamento de Vigilância, Prevenção e Controle das Infecções Sexualmente Transmissíveis, do HIV/Aids e das Hepatites Virais. Protocolo clínico e diretrizes terapêuticas para manejo da infecção pelo HIV em adultos. Brasília: Ministério da Saúde; 2018. [cited 2019 May 6]. Available from: http://www.aids.gov.br/pt-br/pub/2013/protocolo-clinico-ediretrizes-terapeuticas-para-manejo-da-infeccao-pelo-hiv-emadultos

8. Catalan-Soares B, Carneiro-Proietti AB, Proietti FA. Heterogeneous geographic distribution of human T-cell lymphotropic viruses I and II (HTLV-I/II): serological screening prevalence rates in blood donors from large urban areas in Brazil. Cad Saude Publica. 2005;21:926-31.

9. Maresch C, Schluter PJ, Wilson AD, Sleigh A. Residual infectious disease risk in screened blood transfusion from a highprevalence population: Santa Catarina, Brazil. Transfusion. 2008;48:273-81. 
10. Brasil. Ministério da Saúde. Secretaria de Vigilância em Saúde. HIV AIDS 2018. Bol Epidemiol. 2018;49:1-66. [cited 2019 May 6]. Available from: http://www.aids.gov.br/pt-br/ pub/2018/boletim-epidemiologico-hivaids-2018

11. Santa Catarina. Secretaria de Saúde. Diretoria de Vigilância Epidemiológica. Boletim epidemiológico HIV/AIDS 2018: Santa Catarina. Inf Epidemiol Barriga Verde. 2019;15 Ed Esp:1-22. [cited 2019 Sep 10]. Available from: http://www. dive.sc.gov.br/barrigaverde/pdf/BVAidsFINAL2019.pdf

12. Bello G, Zanotto PM, Iamarino A, Gräf T, Pinto AR, CoutoFernandez JC, et al. Phylogeographic analysis of HIV-1 subtype C dissemination in Southern Brazil. PLoS One. 2012;7:e35649.

13. Caterino-de-Araujo A, Sacchi CT, Gonçalves MG, Campos KR, Magri MC, Alencar WK, et al. Current prevalence and risk factors associated with human $\mathrm{T}$ lymphotropic virus type 1 and human $\mathrm{T}$ lymphotropic virus type 2 infections among HIV/AIDS patients in São Paulo, Brazil. AIDS Res Hum Retroviruses. 2015;31:543-9.

14. Campos KR, Gonçalves MG, Caterino-de-Araujo A. Failures in detecting HTLV-1 and HTLV-2 in patients infected with HIV-1. AIDS Res Hum Retroviruses. 2017;33:382-5.

15. Campos KR, Gonçalves MG, Costa NA, Caterino-de-Araujo A. Comparative performances of serologic and molecular assays for detecting human $\mathrm{T}$ lymphotropic vírus type 1 and type 2 (HTLV-1 and HTLV-2) in patients infected with human immunodeficiency virus type 1 (HIV-1). Braz J Infect Dis. 2017;21:297-305.

16. Caterino-de-Araujo A, Santos-Fortuna E, Magri MC, SchuelterTrevisol F, Silva MV. Unpredicted HTLV-1 infection in female sex worker from Imbituba, Santa Catarina, Brazil. Rev Inst Med Trop Sao Paulo. 2006; 48:237-8.

17. Morimoto HK, Caterino-de-Araujo A, Morimoto AA, Reiche EM, Ueda LT, Matsuo T, et al. Seroprevalence and risk factors for human $\mathrm{T}$ cell lymphotropic virus type 1 and 2 infection in human immunodeficiency virus-infected patients attending AIDS Referral Center Health Units in Londrina and other communities in Paraná, Brazil. AIDS Res Hum Retroviruses. 2005;21:256-62.
18. Morimoto HK, Morimoto AA, Reiche EM, Ueda LT, Matsuo $\mathrm{T}$, Reiche FV, et al. Difficulties in the diagnosis of HTLV-2 infection in HIV/AIDS patients from Brazil: comparative performances of serologic and molecular assays, and detection of HTLV-2b subtype. Rev Inst Med Trop Sao Paulo. 2007;49:225-30.

19. Barcellos NT, Fuchs SC, Mondini LG, Murphy EL. Human T lymphotropic virus type I/II infection: prevalence and risk factors in individuals testing for HIV in counseling centers from Southern Brazil. Sex Transm Dis. 2006;33:302-6.

20. Galetto LR, Lunge VR, Béria JU, Tietzmann DC, Stein AT, Simon D. Prevalence and risk factors for human T cell lymphotropic virus infection in Southern Brazilian HIV-positive patients. AIDS Res Hum Retroviruses. 2014;30:907-11.

21. Paiva A, Casseb J. Sexual transmission of human T-cell Lymphotropic virus type 1. Rev Soc Bras Med Trop. 2014;47:265-74.

22. de Araujo AC, Casseb J, Neitzert E, Souza ML, Mammano F, Del Mistro A, et al. HTLV-I and HTLV-II infections among HIV-1 seropositive patients in São Paulo, Brazil. Eur J Epidemiol. 1994;10:165-71.

23. Caterino-de-Araujo A, Santos-Fortuna E, Meleiro MC, Suleiman J, Calabrò ML, Favero A, et al. Sensitivity of two ELISA tests in relation to western blot in detecting HTLV-I and HTLV-II infections among HIV-1-infected patients from São Paulo, Brazil. Diagn Microbiol Infect Dis. 1998;30:173-82.

24. Dourado I, Andrade T, Carpenter CL, Galvão-Castro B. Risk factors for human $\mathrm{T}$ cell lymphotropic virus type I among injecting drug users in Northeast Brazil: possibly greater efficiency of male to female transmission. Mem Inst Oswaldo Cruz, Rio de Janeiro. 1999;94:13-8.

25. Mesquita F, Kral A, Reingold A, Triguerios D, Araujo PJ. Trends of HIV infection among injection drug users in Brazil in the 1990s: the impact of changes in patterns of drug use. J Acquir Immune Defic Syndr. 2001;28:298-302.

26. Mesquita F, Doneda D, Gandolfi D, Nemes MI, Andrade T, Bueno $\mathrm{R}$, et al. Brazilian response to the human immunodeficiency virus/acquired immunodeficiency syndrome epidemic among injection drug users. Clin Infect Dis. 2003;37 Suppl 5:S382-5. 